\title{
Motile Activities of Dictyostelium discoideum Differ from those in Protista or Vertebrate Animal Cells
}

\author{
Agnieszka WALIGÓRSKA, Magdalena WiANECKA-SKOCZEŃ, and Włodzimierz KOROHODA
}

Accepted April 16, 2007

\begin{abstract}
WALIGÓRSKA A., WiAnecKA-SKoczeń M., KorohodA W. 2007. Motile activities of Dictyostelium discoideum differ from those in Protista or vertebrate animal cells. Folia biol. (Kraków) 55: 87-93.

Cell movement in the amoebae Dictyostelium discoideum has been examined in media differing in monovalent cation concentration (i.e. $\mathrm{Na}^{+}$and $\mathrm{K}^{+}$). Under isotonic or even slightly hypertonic conditions, the cells move equally well in solutions in which either potassium or sodium ions dominate. However, in strongly hypertonic solutions the amoebae showed motility in a $2 \%$ potassium chloride solution, but remained motionless in a hypertonic $2 \%$ sodium chloride solution. This inhibition of $D$. discoideum amoebae movement in a hypertonic sodium chloride solution was fully reversible. Such behaviour corresponds to that of plant, fungi, and some invertebrate animal cells rather than protozoan or vertebrate cells. These observations suggest that studies using $D$. discoideum as a model for cell motility in vertebrate animal tissue cells should be considered with caution, and would seem to confirm the classification of cellular slime moulds as related rather to Fungi than to Protista. This also shows that the cell membrane models should consider the asymmetry in sodium /potassium ion concentrations found in vertebrate animal cells as one of various possibilities.
\end{abstract}

Key words: Dictyostelium discoideum, cell movement, sodium and potassium, fungi, osmotic stress.

Agnieszka WALIGÓRSKA, Magdalena WIANECKA-SKOCZEŃ, Włodzimierz KOROHODA, Department of Cell Biology, Faculty of Biochemistry, Biophysics and Biotechnology, Jagiellonian University, Gronostajowa 7, 30-387 Kraków, Poland.

E-mail: korohoda@mol.uj.edu.pl

Abbreviations: PMNL - Polymorphonuclear leukocytes, $D$. discoideum - Dictyostelium discoideum, BSS - basal or basic salt solution.

The social amoebae $D$. discoideum is easy to grow in the laboratory and movement can be observed in simple mineral salt solutions in the absence of extracellular macromolecules at room temperature (BONNER 1982; KESSIN 2001). In recent years these amoebae have been considered as model cells for research on cell movement. It is often assumed that studies of motile activities of amoebae of $D$. discoideum yield results valid for other amoebae and cells from a variety of tissues (CONDEElis 1998; Wessels \& SOll 1998).

In many aspects, the movements of $D$. discoideum amoebae resemble the activities of white blood cells or neoplastic cells. When well fed, $D$. discoideum amoebae migrate with flat lamellipodia resembling those of fibroblast-like cells, but when starved they move with bleb-like surface protrusions resembling those in PMNL, Walker cancer cells, primary mesenchyme embryo cells, and other types of amoebae (ALEXANDER et al. 1992; WEBER et al. 1995). These amoebae are haploid which makes them suitable for genetic manipulations and macromolecular study (ARKOWITZ 1999; EICHINGER \& NOEGEL 2003; FAIX et al. 2004; SCHLEICHER et al. 1988; SCHLENKRICH et al.1995; SPUDICH 1989). Nevertheless, some features displayed by these cells provoke concerns as to their relevance to vertebrate animal tissue cell motility. For example $D$. discoideum amoebae react to chemoattractants even when their membranes are depolarised (VAN DUIJN et al. 1989, VAN DUIJN et al. 1990), whereas vertebrate animal cells and amoebae of the proteus type (which belong to Protista) remain motionless under such conditions. The observations reported here concern features of motility in $D$. discoideum amoebae that are not common to other amoebae or tissue cells of vertebrate animals, which raises the question to what extent the results of research carried out on $D$. discoideum amoebae can be generalized to other cell types showing amoeboid movement. 


\section{Material and Methods}

\section{Cell Culture}

D. discoideum strain AX-2 (ATCC24397) was cultured as described previously (KOROHODA et al. 2002, SROKA et al. 2002) in medium containing: $14.3 \mathrm{~g} / 1$ meat peptic pepton (Oxoid Ltd, England), $7.15 \mathrm{~g} / 1$ yeast extract (BioMerieux, France), $18 \mathrm{~g} / 1$ maltose (Sigma St. Louis, MO), $1.28 \mathrm{~g} / 1$ $\mathrm{Na}_{2} \mathrm{HPO}_{4} \times 12 \mathrm{H}_{2} \mathrm{O}, 0.48 \mathrm{~g} / 1 \mathrm{KH}_{2} \mathrm{PO}_{4}$, pH 7.4. The cells were grown in suspension at $20^{\circ} \mathrm{C}$, harvested at the exponential growth stage, washed three times with Chalkley's medium $(14 \mathrm{mM} \mathrm{NaCl}$, $0.27 \mathrm{mM} \mathrm{KCl}, 0.5 \mathrm{mM} \mathrm{CaCl}, 0.5 \mathrm{mM} \mathrm{MgCl}_{2}$ ) (HABEREY \& STOCKEM 1971, KOROHODA \& STOCKEM 1975) or Basic Salt Solution (20mM $\mathrm{KCl}, 2.5 \mathrm{mM} \mathrm{MgCl} 2,20 \mathrm{mM} \mathrm{KH}_{2} \mathrm{PO}_{4}$ ) (WESSELS et al. 2004), resuspended in an appropriate medium (Chalkley's solution or BSS) and plated in Petri dishes.

\section{Cellular motility under isotropic conditions}

The motility of $D$. discoideum cells in Chalkley's medium and in Basic Salt Solution (BSS) was observed after spreading in a Petri dish and recorded for 20 minutes as described below.

\section{Cellular motility in hypertonic solutions}

Experiments with cells migrating in hypertonic solutions were conducted in $1 \%$ and $2 \% \mathrm{NaCl}$ and $\mathrm{KCl}$ solutions in distilled water. The cells were washed three times with Chalkley's medium (for $\mathrm{NaCl}$ experiments) or Basic Salt Solution (for $\mathrm{KCl}$ experiments), resuspended in the appropriate medium for attachment to the Petri dish substratum, approximately $30 \mathrm{~min}$. Next, the medium was changed to $1 \%$ or $2 \% \mathrm{KCl}$ or $1 \%$ or $2 \% \mathrm{NaCl}$ and the cells were incubated in these hypertonic solutions. After 4 hours the cells were recorded for 20 minutes with images obtained every 20 seconds.

Osmolality of each solution was determined using a freezing point osmometer (Marcel os3000).

\section{Recording of cellular motility}

Cell migration was observed with an inverted Hund Wilovert S microscope, recorded with a Hitachi CCD camera, digitised and processed with programs written by P. Jochym and R. Tokarski. Images were acquired every 20 s for 20 minutes. Tracks of individual cells were generated as described previously (KOROHODA \& MADEJA 1997; KOROHODA et al. 1997), by determination of the cell centroid position from each frame. Trajectories were composed of 60 sequential centroid posi- tions, and the program Mathematica was used for further data processing.

\section{Analysis of cellular motility}

The following parameters characterising cell locomotion were computed for each cell or cell population:

- the total length of the cell trajectory,

- the average speed of cell movement - defined as the total length of the cell trajectory/time of recording (20 min.),

- the total length of cell displacement - the distance between the first and the last points of the cell track,

- the average rate of cell displacement - defined as the length of final cell displacement/time of recording (20 min.),

- coefficient of movement efficiency (CME) the ratio of cell displacement to cell trajectory length; the CME would equal 1 for the cells moving persistently along one straight line and 0 for a random movement.

The cell trajectories were presented in circular diagrams with the starting point of each trajectory located in the diagram centre (GRULER \& NUCCITELLI 1991; KOROHODA \& MADEJA 1997).

Statistical significance was determined by the Student's $t$ test or nonparametric Mann-Whitney test, with $\mathrm{P}<0.05$ considered significant.

Percentage of $D$. discoideum amoebae migrating in hypertonic solutions $(2 \%$ solutions of $\mathrm{KCl}$ or $\mathrm{NaCl})$

Cell movement in hypertonic solutions was recorded for 8 hours, the images were acquired every 180 seconds, and again after 24 hours of incubation for 1 hour. In order to determine the ability of D. discoideum cells to migrate after 2, 4, 8 and 24 hours of incubation in hypertonic medium, each recorded cell was contoured at the moment when it stopped migration $\left(\mathrm{t}_{0}\right)$ and again after 2, 4, 8 and 24 hours of incubation. Cells were considered migrating if their projections after that time did not share any area with their projections at $t_{0}$.

\section{Results}

It has recently been observed that in contrast to some reports concerning various tissue cells, the spreading and locomotion of $D$. discoideum amoebae is not inhibited in strongly hypertonic media but on the contrary, after a short adaptation period, is significantly accelerated. The effects of hypertonic media appeared to depend more on the type 
A

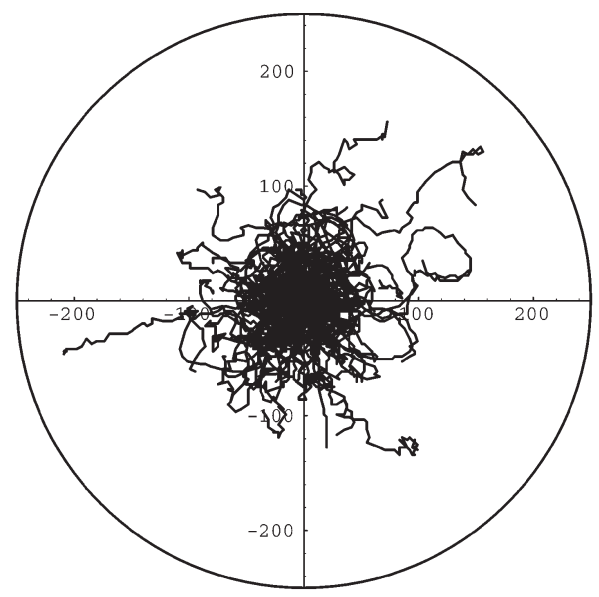

C

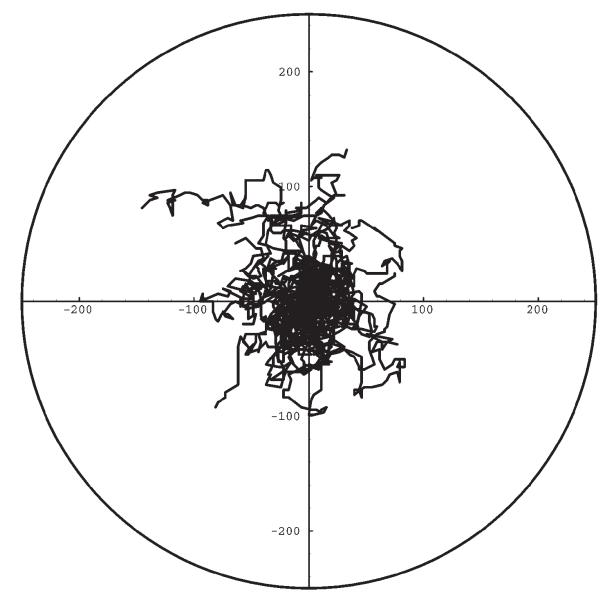

E

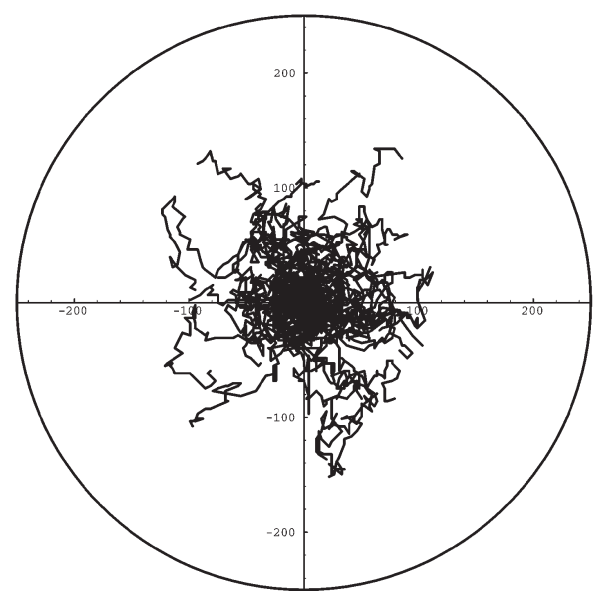

B

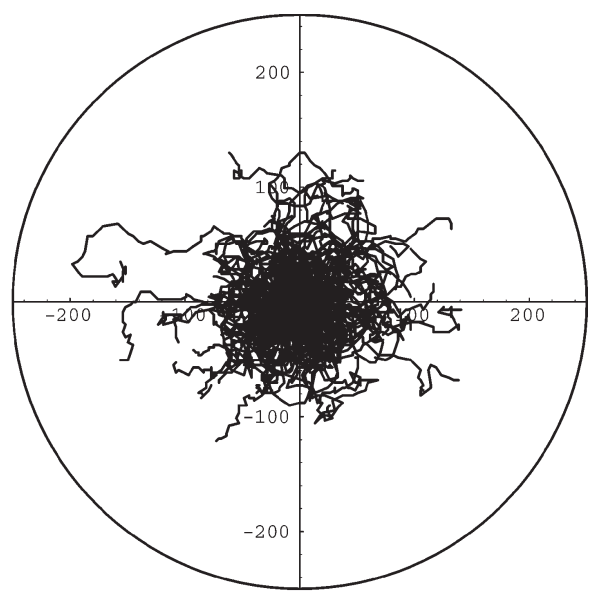

D

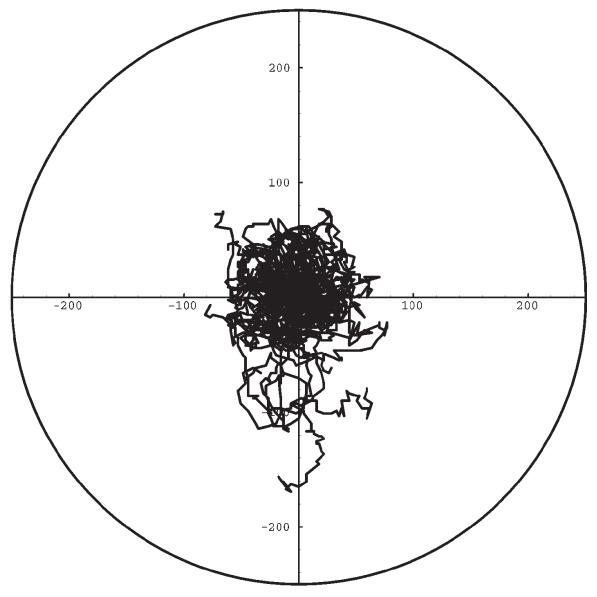

$\mathbf{F}$

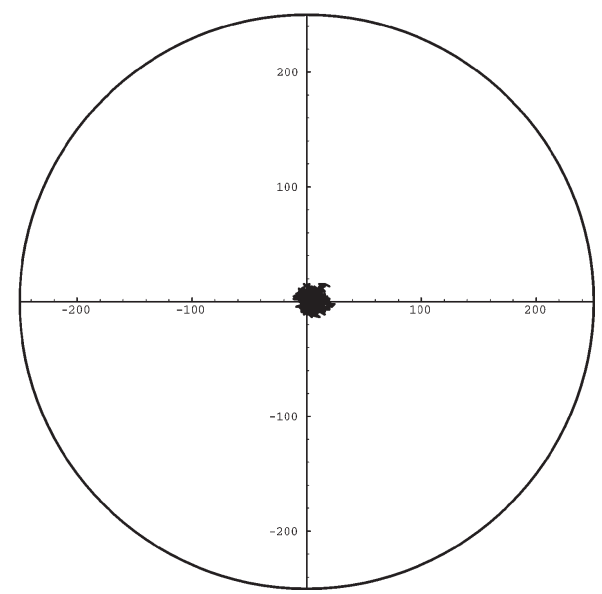

Fig. 1. Trajectories of D. discoideum amoebae migrating in isotropic conditions: A - in Chalkley's medium ( $\mathrm{n}=100)$, $\mathrm{B}-$ in BSS medium $(n=100)$; and in hypertonic solutions of $\mathrm{KCl}$ and $\mathrm{NaCl}$ in distilled water $(\mathrm{C}-\mathrm{F}): \mathrm{C}-1 \% \mathrm{KCl}(\mathrm{n}=50), \mathrm{D}-1 \%$ $\mathrm{NaCl}(\mathrm{n}=50), \mathrm{E}-2 \% \mathrm{KCl}(\mathrm{n}=50)$ and $\mathrm{F}-2 \% \mathrm{NaCl}(\mathrm{n}=50)$. All after 4 hours of incubation. After 4 hours of incubation cells were recorded for 20 minutes and each trajectory was constructed from 60 successive points of the cell centroid positions at 20 s intervals. In all diagrams the initial point for each trajectory was placed at the centre of the circle. 
Table 1

Values of parameters characterising cell movement of $D$. discoideum amoebae in various solutions

\begin{tabular}{||c|c|c|c|c|c|c||}
\hline \multicolumn{1}{|c|}{$\begin{array}{c}\text { Parameters characterising } \\
\text { cell movement } \\
( \pm \mathrm{SEM})\end{array}$} & $\begin{array}{c}\text { BSS } \\
\text { solution } \\
(\mathrm{n}=100)\end{array}$ & $\begin{array}{c}\text { Chalkley's } \\
\text { solution } \\
(\mathrm{n}=100)\end{array}$ & $\begin{array}{c}1 \% \mathrm{KCl} \\
(\mathrm{n}=50)\end{array}$ & $\begin{array}{c}1 \% \mathrm{NaCl} \\
(\mathrm{n}=50)\end{array}$ & $\begin{array}{c}2 \% \mathrm{KCl} \\
(\mathrm{n}=50)\end{array}$ & $\begin{array}{c}2 \% \mathrm{NaCl} \\
(\mathrm{n}=50)\end{array}$ \\
\hline \hline Total length of cell trajectory $[\mu \mathrm{m}]$ & $310.52 \pm 6.02$ & $283.46 \pm 6.63$ & $416.83 \pm 13.53 * \# 332.1 \pm 11.8 * 347.12 \pm 9.1^{* \#}$ & - \\
\hline Average speed of cell movement $[\mu \mathrm{m} / \mathrm{min}]^{1)}$ & $15.5 \pm 0.3$ & $14.17 \pm 0.3$ & $20.84 \pm 0.67 * \#$ & $16.6 \pm 0.59^{*}$ & $17.35 \pm 0.45^{* \#}$ & - \\
\hline Total length of cell displacement $[\mu \mathrm{m}]$ & $66.6 \pm 3.79 *$ & $54.48 \pm 4.18$ & $58.23 \pm 6.92$ & $43.85 \pm 4^{* \#}$ & $75.77 \pm 5.6^{*}$ & - \\
\hline Average rate of cell displacement $[\mu \mathrm{m} / \mathrm{min}]^{2)}$ & $3.3 \pm 0.18^{*}$ & $2.75 \pm 0.2$ & $2.9 \pm 0.35$ & $2.2 \pm 0.2^{*} \#$ & $3.7 \pm 0.28^{*}$ & - \\
\hline Coefficient of movement efficiency $(\mathrm{CME})^{3)}$ & $0.22 \pm 0.01$ & $0.19 \pm 0.01$ & $0.15 \pm 0.02$ & $0.14 \pm 0.01$ & $0.23 \pm 0.017$ & - \\
\hline
\end{tabular}

1) The average speed of cell movement is defined as the total length of cell trajectory/time of recording (20 min.)

${ }^{2)}$ The average rate of cell displacement is defined as the length of final cell displacement/time of recording (20 min.)

${ }^{3)}$ Coefficient of movement efficiency - the ratio of cell displacement to cell trajectory length

* statistical significance at $\mathrm{P}<0.05$ vs. parameters of cells in Chalkley's medium

\# statistical significance at $\mathrm{P}<0.05$ vs. parameters of cells in BSS medium

Table 2

Percentage of $D$. discoideum amoebae migrating in hypertonic solutions of $2 \% \mathrm{NaCl}$ and $2 \% \mathrm{KCl}$ in distilled water determined at different time intervals

\begin{tabular}{|l|c|c|c|c|}
\hline \multirow{3}{*}{} & \multicolumn{4}{|c||}{ Percentage of cells migrating in hypertonic solutions } \\
\cline { 2 - 5 } & \multicolumn{4}{|c||}{ Time of incubation in hypertonic solution } \\
\cline { 2 - 5 } & $2 \mathrm{~h}$ & $4 \mathrm{~h}$ & $8 \mathrm{~h}$ & $24 \mathrm{~h}$ \\
\hline $2 \% \mathrm{NaCl}$ & 0 & 0 & 0 & 0 \\
\hline $2 \% \mathrm{KCl}$ & 48 & 92 & 98 & 98 \\
\hline
\end{tabular}

of solute than upon water activity and reduction of cell volume. The experiments presented in this communication concerned therefore the effects of cation $\left(\mathrm{Na}^{+} / \mathrm{K}^{+}\right)$composition and osmolality of media upon movement of $D$. discoideum amoebae under isotropic conditions (WALIGÓRSKA et al. 2007). As shown in Figures $1 C, 1 D$ and Table 1, D. discoideum amoebae, in contrast to vertebrate animal tissue cells and amoebae of the chaos-proteus group (Protista), continued movement for hours not only in Chalkley's medium, used for culture of protozoan cells, equally as well as in BSS solution (Fig. 1A and Fig. 1B), but even in pure $1 \% \mathrm{KCl}$ and $1 \% \mathrm{NaCl}$ solutions in distilled water.

In a search for more discriminating conditions, the movement of $D$. discoideum amoebae in strongly hypertonic conditions was compared in $2 \% \mathrm{KCl}$ and $2 \% \mathrm{NaCl}$ in distilled water (for comparison: osmolality of Chalkley's solution is 35.3,
BSS $-88.6,2 \% \mathrm{KCl}-587.5$, and $2 \% \mathrm{NaCl}-670.5$ $\mathrm{mOsm} / \mathrm{kg} \mathrm{H}_{2} \mathrm{O}$ ). The results are presented in Figure $1 \mathrm{E}, 1 \mathrm{~F}$, Table 1, Figure 2 and Table 2. Whereas in a $2 \% \mathrm{NaCl}$ solution amoebae stopped locomotion and remained standstill for hours (we checked up to the $6 \mathrm{~h}$ ), in a $2 \% \mathrm{KCl}$ solution the cells continued active movement. Even in $3 \% \mathrm{KCl}$ in distilled water about $30 \%$ of amoebae were still able to move for at least $3 \mathrm{~h}$ (data not shown) which clearly shows that an osmotic effect is not responsible for the inhibition of $D$. discoideum amoebae movement in the simple, strongly hypertonic solution of sodium chloride in distilled water. The inhibition of cell movement in $2 \% \mathrm{NaCl}$ appeared fully reversible. On return to more diluted solutions, more than $95 \%$ of cells resumed active locomotion which confirmed that motionless amoebae remained alive during time spent motionless. 


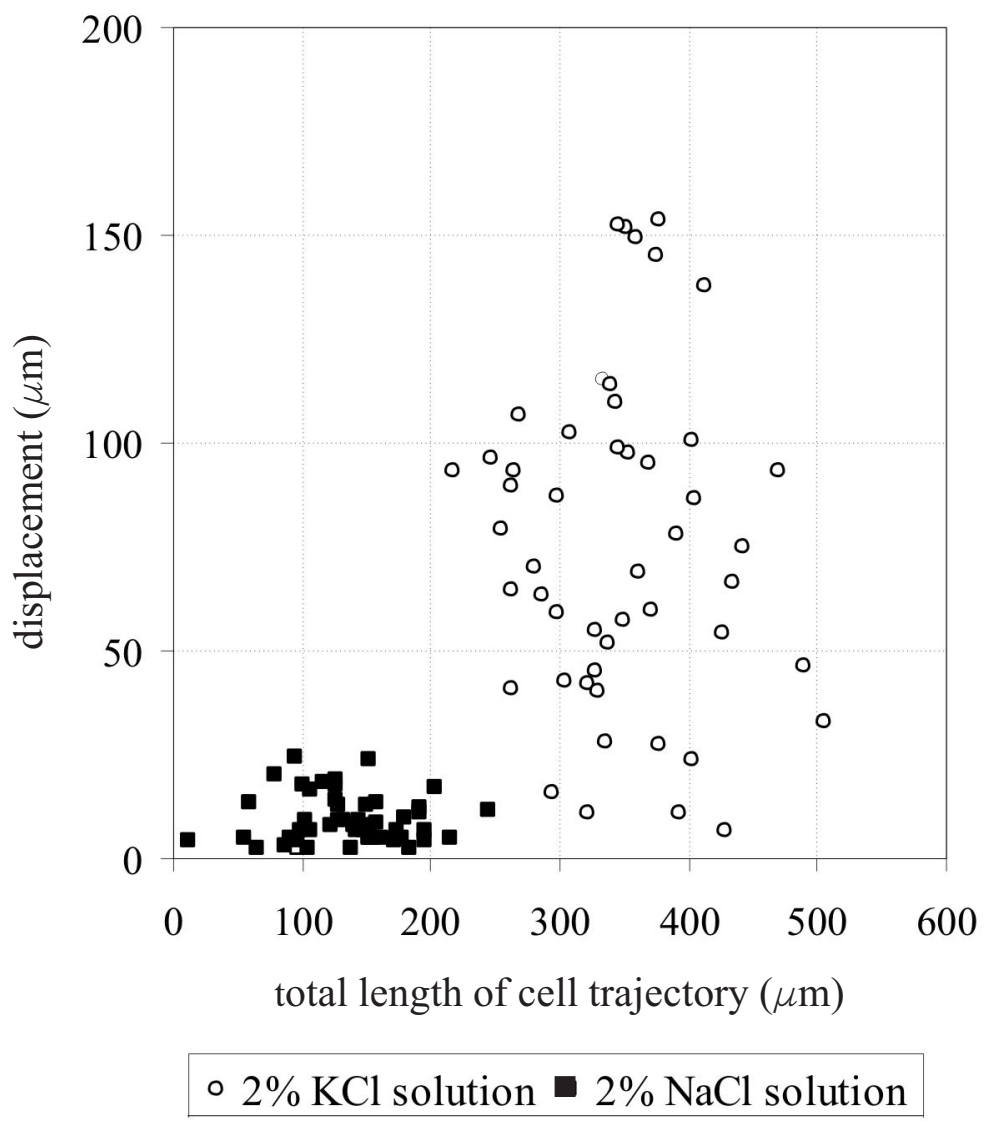

Fig. 2. Scatter correlation diagram of total trajectory and displacement of $D$. discoideum cells migrating under hypertonic conditions in $2 \% \mathrm{KCl}$ and in $2 \% \mathrm{NaCl}$ in distilled water, after $4 \mathrm{~h}$ of incubation $(\mathrm{n}=50)$.

\section{Discussion}

We observed that $D$. discoideum amoebae moved equally well in low osmolality media in which sodium ions dominate (Chalkley's medium used for culture of Protista) as in a BSS solution, in which the potassium ion is the only monovalent cation (cf. Fig. 1A, 1B). Furthermore, they were able to continue movement for hours in pure $1 \% \mathrm{NaCl}$ or $1 \% \mathrm{KCl}$ solutions in distilled water (Fig. 1C, 1D). This behaviour differs dramatically from the behaviour of mammalian and bird cells and also of large amoebae in $1 \% \mathrm{KCl}$. In solutions in which the cell membrane is depolarised, large amoebae and tissue cells are unable to locomote and their cytoplasm is reversibly liquefied (ALLEN 1961; HEILBRUNN \& DAUGHERTY 1932; SERAVIN 1967). Since in a $\mathrm{KCl}$ solution the cell membrane is depolarised, this observation seems to correspond with the conclusion of VAN DUIJN that $D$. discoideum amoebae, in contrast to many other cell types, can move with depolarised membranes (VAN DUIJN et al. 1990). This suggests that research using $D$. discoideum amoebae as a model for animal tissue cells should be considered and generalized with caution. Additionally, all media and salt solutions used for vertebrate cell culture contain sodium ions at much higher concentrations than potassium ions. In contrast, salt solutions in media used for culture of fungi cells, plant cells or even some cells of invertebrates often contain more potassium than sodium ions (cf. catalogues giving the composition of cell culture media, for example any medium for plant cell culture, or Grace's insect medium - Sigma 1998 catalogue). There is no clear explanation for this basic difference in various cell requirements concerning the ionic composition of suitable media and the problem itself seems of interest. Fungi, plants and many invertebrates live in conditions in which potassium ions prevail and this may reflect environmental adaptation, but its mechanisms remain unexplained. Here we only point out that caution is required for generalization of results of research carried out with fungi to mammalian cells, in spite of the well known occurrence of similar protein families in both groups of organisms (CONDEELIS 1998; EICHINGER et al. 2005; KESSIN 2001; SCHLEICHER et al. 1988). 
Cellular social slime moulds, Acrasiae, had been classified as Fungi and hence called Myxomycestes, or to Protista and called Mycetozoa. More recently, on the grounds of genetic and proteomic studies it was suggested that Dictyostelium is an eukaryote related to animals, fungi, and Acanthamoebae (EICHINGER et al. 2005).

In discussions of cell membrane properties it is often postulated that the electric field related to the asymmetric distribution of sodium and potassium ions acting on plasma membrane molecules of vertebrate animal cells is a general phenomenon present in all eukaryotic cells. It is assumed that the sodium ion concentration is always higher in extracellular solutions than in cytoplasm and the reverse ratio characterises the distribution of potassium ions. The results presented in this report show that in many organisms (plant, fungi, invertebrate animals), the extracellular concentration of potassium may be higher than the sodium and intracellular potassium concentrations.

Observations of $D$. discoideum amoebae movement incubated for $3 \mathrm{~h}$ in strongly hypertonic solutions of $2 \%$ and $3 \% \mathrm{KCl}$ reveal the need for a revision of the commonly expressed view on the behaviour of cells under hypertonic conditions and cell responses to so called "osmotic stress". In the past it was even postulated by some authors that cells are not able to produce pseudopodia and do not move in hypertonic solutions and that osmotic forces play a causal role in cell shape changes (FEDIER \& KELLER 1997; OSTER \& PERELSON 1987; UEDA \& OGIHARA 1994; ZISCHKA et al. 1999). These problems require separate experiments and discussion and shall be considered in forthcoming papers.

\section{Acknowledgements}

This work was supported by grant PB 2P04C 00828 and PB 2P04C 12529 from the Polish Ministry of Scientific Research and Information Technology. The authors cordially thank prof. D. E. WOOLLEY, University of Manchester, UK for valuable discussions and language correction.

\section{References}

ALEXANDER S., SYDOW L. M., WesSEls D., SOlL, D. R. 1992. Discoidin proteins of Dictyostelium are necessary for normal cytoskeletal organization and cellular morphology during aggregation. Differentiation 51: 149-161.

ALLEN R. D. 1961. Ameboid movement. (In: The Cell. J.Brachet, A.E. Mirsky eds., Academic Press, New York and London) 2: 135-216.

ARKOWITZ R. A. 1999. Responding to attraction: chemotaxis and chemotropism in Dictyostelium and yeast. Trends in Cell Biol. 9: 20-27.

BONNER J. T. 1982. Evolutionary strategies and developmental constraints in the cellular slime molds. The American Naturalist 119: 530-552.
CONDEELIS J. 1998. The biochemistry of animal cell crawling. (In: Motion Analysis of Living Cells, D. R. SOLL and D. WESSELS eds., Wiley-Liss, Inc., New York, Toronto): 85-100.

EICHINGER L., NOEGEL A. A. 2003. Crawling into a new erathe Dictyostelium genome project. EMBO J. 22: 1941-1946.

EICHINGER L., PACHEBAT J. A., GLOCKNER G., RAJANDREAM M. A., SUCGANG R., BERRIMAN M., SONG J., OLSEN R., SZAFRANSKI K., XU Q., TUNGGal B., KUMMERFELD S., MADERA M., KONFORTOV B. A., RIVERO F., BANKIER A. T., LEHMANN R., HAMLIN N., DAVIES R., GAUDET P., FEY P., PILCHER K., CHEN G., SAUNDERS D., SODERGREN E., DAVIS P., KERHORNOU A., NIE X., HALL N., ANJARD C., HEMPHILl L., BASON N., FARBROTHER P., DESANY B., Just E., MORIO T., ROST R., ChuRCher C., COOPER J., HAYDOCK S., VAN DRIESSCHE N., CRONIN A., GOODHEAD I., MUZNY D., MOURIER T., PAIN A., LU M., HARPER D., LiNDSAY R., HAUSER H., JAMES K., QUILES M., MADAN BABU M., SAITO T., BUCHRIESER C., WARDROPER A., FELDER M., THANGAVELU M., JOHNSON D., KNIGHTS A., LOUlSEGED H., MUNGALl K., OlIVER K., PRICE C., QUAIL M. A., URUShIHARA H., HERNANDEZ J., RABBINOWITSCH E. STEFFEN D., SANDERS M., MA J., KOHARA Y., SHARP S., SimmondS M., SPIEGLER S., TIVEY A., SUgANO S., WHITE B., WALKER D., WOODWARD J., WINCKLER T., TANAKA Y., SHAULSKY G., SCHLEICHER M., WEINSTOCK G., Rosenthal A., COX E. C., ChISHOLM R. L., GiBBS R., LOOMIS W. F., PlatZer M., KAY R.R., Williams J., DEAR P. H., NOEGEL A. A., BARRELL B., KUSPA A. 2005. The genome of the social amoeba Dictyostelium discoideum. Nature 435: 43-57.

FaiX J., Kreppel L., Shaulsky G., Schleicher M., KIMMEL A. R. 2004. A rapid and efficient method to generate multiple gene disruptions in Dictyostelium discoideum using a single selectable marker and the Cre-loxP system. Nucleic Acids Res. 32: e143.

FEDIER A., KELLER H. U. 1997. Suppression of bleb formation, locomotion, and polarity of Walker carcinosarcoma cells by hypertonic media correlates with cell volume reduction but not with changes in the F-actin content. Cell Motil. Cytoskel. 37: 326-337.

GRULER H., NUCCITELLI R. 1991. Neural crest cell galvanotaxis: new data and a novel approach to the analysis of both galvanotaxis and chemotaxis. Cell Motil. Cytoskeleton. 19: 121-133.

HABerey M., STOCKeM W. 1971. Amoeba proteus morphologie, zucht und verhalten. Mikrokosmos 60: 33-42.

HEILBRUNN L. V., DAUGHERTY K. 1932. The action of sodium, potassium, calcium and magnesium ions on the plasmagel of Amoeba proteus. Physiol. Zool. 5: 254-274.

KESSIN R. H. 2001. Dictyostelium. Evolution, Cell Biology, and the Development of Multicellularity. (Cambridge University Press, Cambridge): 1-294.

Korohoda W., GOlda J., SROKa J., WoJNAROWicZ A., JOCHYM P., MADEJA Z. 1997. Chemotaxis of Amoeba proteus in the developing $\mathrm{pH}$ gradient within a pocket-like chamber studied with the computer assisted method. Cell Motil Cytoskeleton 38: 38-53.

KOROHODA W., MADEJA Z. 1997. Contact of sarcoma cells with aligned fibroblasts accelerates their displacement: computer-assisted analysis of tumour cell locomotion in coculture. Biochem. Cell Biol. 75: 263-276.

Korohoda W., MADEJA Z., SROKA J. 2002. Diverse chemotactic responses of Dictyostelium discoideum amoebae in the developing (temporal) and stationary (spatial) concentration gradients of folic acid, cAMP, $\mathrm{Ca}^{2+}$ and $\mathrm{Mg}^{2+}$. Cell Motil Cytoskeleton 53: 1-25.

KOROHODA W., STOCKEM W. 1975. On the nature of hyaline zones in the cytoplasm of Amoeba proteus. Microscopica Acta 77: 129-141.

OSTER G. F., PERELSON A. S. 1987. The physics of cell motility. J. Cell Sci. Suppl. 8: 35-54.

SChleicher M., NoEgel A., SCHWARZ T., WALlRafF E., BRINK M., FAIX J., GERISCH G., ISENBERG G. 1988. A Dictyostelium mutant with severe defects in alpha-actinin: its characterization using cDNA probes and monoclonal antibodies. J Cell Sci. 90: 59-71.

SCHLENKRICH T., PORST M., HADER D. P. 1995. A rapid, simple method for the isolation and characterization of the 
photoreceptor of Dictyostelium discoideum amoebae. FEBS Lett. 364: 276-278

SERAVIN L. H. 1967. Dvigatielnyje sistemi prostieisix. Nauka, Leningrad, 1-332.

Sigma Catalogue and price list. 1998. - Cell culture. Liquid and Powdered Media. 1-294.

SPUDICH J. A. 1989. In pursuit of myosin function. Cell Regul. 1: 1-11.

Sroka J., Madeja Z., Michalik M., PrZestalski S., KOROHODA W 2002. Folic acid, ascorbic acid and sodium selenite restore the motility of Dictyostelium discoideum inhibited by triethyllead. Toxicology 180: 275-292.

UedA M., OGIHARA S. 1994. Microtubules are required in amoeba chemotaxis for preferential stabilization of appropriate pseudopods. J. Cell Sci. 107: 2071-2079.

VAN DUIJN B., VAN DER MOLEN L. G., YPEY D. L. 1989. Effects of potassium channel blockers on differentiation of Dictyostelium discoideum. Pflugers Arch. 414: S148-S149.

VAN DUIJN B., VOGELZANG S. A., YPEY D.L., VAN DER MOLEN L.G., VAN HAASTERT P.J. 1990. Normal chemotaxis in Dictyostelium discoideum cells with a depolarized plasma membrane potential. J Cell Sci. 95: 177-183.
WALIGORSKA A., WIANECKA-SKOCZEN M., NOWAK P KOROHODA W. 2007. Some difficulties in research into celi motile activity under isotropic conditions. Folia biol. (Kraków) 55: 9-16.

Weber L., Wallraff E., Albrecht R., Gerisch R. 1995. Motility and substratum adhesion of Dictyostelium wildtype and cytoskeletal mutant cells: a study by RICM/brightfield double-view image analysis. J. Cell Sci. 108: $1519-1530$

Wessels D., BRINCKS R., KUHL S., STEPANOVIC V., DANIELS K. J., WEEKS G., LIM C. J., SPIEGELMAN G., FULLER D., IRANFAR N. LOOMIS W. F., SOLL D. R. 2004 .' RasC plays a role in transduction of temporal gradient information in the cyclic-AMP wave of Dictyostelium discoideum. Eukaryot Cell 3: 646-662.

WESSELS D., SOLL D: R. 1998. Computer-assisted characterization of the behavioral defects of cytoskeletal mutants of Dictyostelium discoideum. (In: Motion Analysis of Living Cells. D. R. SOLL, D. WESSELS eds, Wiley-Liss, Inc., New York, Toronto): 101-140.

ZisCHKA H. OEHME F. PINTSCH T. OTT A., KELLER H. KELLERMANN J., SCHUSTER S. C. 1999: Rearrangement of cortex proteins constitutes an osmoprotective mechanism in Dictyostelium. EMBO J. 18: 4241-4249. 